удК 347.4

DOI https://doi.org/10.32837/apdp.v0i83.116

П. Д. Гуйван

\title{
СВОЄЧАСНЕ ВИКОНАННЯ ОСТАТОЧНИХ СУДОВИХ ВЕРДИКТІВ В УКРАЇНІ ЗАЛИШАЄТЬСЯ ХРОНІЧНОЮ ПРОБЛЕМОЮ
}

У правозастосовній площині верховенство права відбувається через судове рішення, яке справедливо вважається основою розв'язання тих чи інших спірних питань на шляхом застосування якісного та гуманного законодавства. Це судовий акт, який приймає суд при вирішенні будь-яких питань у межах судочинства, що $€$ процесуальною формою суджень або волевиявлення суду владного характеру. Але саме рішення, хоч яким справедливим би не було, набуває ілюзорного характеру, якщо воно не виконується.

Дієвість судової системи визначається не лише наявністю законних та справедливих вердиктів, а й їхнім виконанням [1, с. 625]. В ідеалі, звісно, було б бажаним, аби усі рішення, що набрали законної сили, виконувалися добровільно, але поки що про такий хід подій не мріють навіть самі демократичні легіслатури світу, тож у правовій системі кожної держави відведене окреме місце для юридичного опосередкування діяльності різних державних та приватних структур, покликаних виконувати остаточні судові рішення. Від їхньої дієвості залежить рівень довіри громадян до держави, у тому числі авторитет судової влади.

3 огляду на необхідність отримання ефективного захисту прав людини своєчасне виконання вердиктів суду має визначальне значення. Це правило є особливо важливим для української національної правової системи. Звісно, за останні роки в Україні судові рішення стали виконувати частіше: виконання зросло з 5-6\% до $18 \%$, але цього все одно недостатньо, щоб досягти середньоєвропейського рівня. У країнах $€ \mathrm{C}$ - це $50-70 \%$. [2]. Відтак, питання тривалості виконання судових рішень $€$ найболючішим саме у нашій державі. Вказане яскраво ілюструється величезною кількістю справ у Європейському суді за скаргами до держави України якраз з приводу незабезпечення належної організації виконавчих процесів. Найбільш показовим прикладом може слугувати справа «Бурмич та інші проти України», в якій суд констатував хронічний характер цієї проблеми, об'єднавши в одному провадженні понад 12 тисяч подібних справ і надавши Україні час до жовтня 2020 року для усунення системних недоліків щодо своєчасного виконання вказаних рішень. Тож часу на виконання рішення ЄСПЛ у цій справі залишилося не так вже й багато, а позитивних зрушень поки що не вбачається. Але це лише надводна частина айсбергу. Набагато більше випадків, які не дійшли до стану розгляду в Європейському суді, але вони якраз найбільше характеризують негатив ситуації.

Подібний стан речей шкодить не лише конкретним особам, які не можуть отримати виконання остаточних рішень судів, що набрали чинності часто після надзвичайно тривалого розгляду, але також серйозно підриває авторитет нашої країни як такої, яка не спроможна навести лад у цій сфері. Тож, де-факто ситуація із виконанням судових рішень в Україні потребує суттєвого вдосконалення, адже у цьому плані 
наше вітчизняне законодавство має значну кількість вад, а в деяких випадках здається, що окремі його положення спеціально напрацьовані для того, аби торпедувати виконавчий процес. До прикладу, серйозною вадою українського законодавства про виконавче провадження є практична неконтрольованість виконавця з боку учасників провадження, і в першу чергу - стягувача. Виконавець із різних суб'єктивних підстав може взагалі не виконувати окремих передбачених законом процесуальних дій, при цьому не ризикуючи отримати якесь матеріальне покарання.

Скажімо, у виконавчому провадженні № 15771498 [3], відкритому ще наприкінці 2009 року за рішенням суду про стягнення коштів з боржника - Кредитної спілки «Аккорд» на користь позивача Г., упродовж всього часу донині (привітаємо себе, в листопаді 2019 року буде своєрідний «ювілей» цього безрезультатного провадження) жодних дій державний виконавець ВДВС Шевченківського РУЮ у м. Києві не вчиняв попри те, що остаточне рішення у справі № 2-2339/09 було забезпечене арештом коштів боржника у банку. Отже, протягом досить значного строку кошти, якими забезпечувалося виконання рішення, спокійнісінько лежали у банку, а виконавець проявляв бездіяльність, що викликає серйозні роздуми і підозри про кримінально-карані та корупційні зв’язки між виконавцем і боржником, інакше ніяк подібну бездіяльність пояснити не можна. Коли ж у 2017 році стягувач звернувся до виконавця із запитом щодо надання інформації про хід виконавчого процесу, заходи, здійснені на виконання рішення (зрештою, може кошти вже стягнуті, але чомусь не надійшли стягувачу), останній упродовж майже року ігнорував подібні запити.

Відтак, аби хоча б якось зрушити мертвий процес, стягувач мусив ініціювати судову справу проти виконавця і зобов'язати останнього надати стягувачеві інформацію про хід виконання рішення у його справі та про заходи, вжиті у цьому процесі. Втім, це не дуже пришвидшило розвиток подій, за українською традицією, керуючись юридичною безкарністю, державний виконавець повністю проігнорував відповідне судове рішення. Лише коли представник стягувача звернувся зі скаргою про подібне нехтування національними законами органами виконання судових рішень персонально до Міністра юстиції України, судове рішення виконавчою службою було виконане, інформація про хід виконавчого процесу була надіслана стягувачеві. Але подібне вирішення проблемних питань $є$ системно неправильним. Кожен мусить виконувати притаманні йому дії, а в законі повинен бути передбачений відповідний запобіжник, який унеможливлює подібне нехтування законами будь-якою особою, який би поважний статус вона не мала.

Як виявилося із листа виконавця Відділу державної виконавчої служби Шевченківського районного управління юстиції у м. Києві, отриманого вже в 2018 році, виконавцю, виявляється, було що приховувати, тож він умисно не інформував стягувача та порушував в цій частині закон. Зі змісту цього допису випливало, що ще у 2014 році виконавче провадження № 15771498 у справі № 2-2339/09 було закінчене на підставі правил ч. 2,4 ст. 49 Закону України «Про виконавче провадження». Тож процес вимушено зрушив у дещо іншому напрямі - до з'ясування правомірності закінчення виконавчого провадження. Чи існували для цього встановлені законом підстави, адже, як би того не хотіли працівники виконавчої служби, ці 
питання, зрештою, стали предметом дослідження у суді після отримання інформації про вказане діяння.

Закриваючи виконавче провадження у справі № 2-2339/09, державний виконавець обгрунтував таку дію правилами п. 2), 4) ч. 1 Закону України «Про виконавче провадження» від 1999 року, а саме «Виконавче провадження підлягає закінченню у разі: 2) визнання судом мирової угоди між стягувачем і боржником у процесі виконання». Використовуючи цю підставу, державний виконавець стверджував, у 2013 році розпочалося банкрутство КС «Аккорд». В межах цього провадження 25 червня 2014 року господарським судом затверджено мирову угоду щодо вимог визнаних кредиторів, серед яких є і стягувач у справі № 2-2339/09. За цією угодою борги кредитної спілки були частково списані, а частково розстрочені до кінця 2022 року. На цій підставі виконавча служба дійшла абсолютно невиважених та таких, що не грунтуються на законі, національному та європейському правозастосуванні та, зрештою, здоровому глузді висновків. Вона вважає, що дана мирова угода оновлює усі існуючі зобов'язання між кредитором і боржником (відбувається новація).

При цьому виконавець у суді при оскарженні подібної дії посилався на позицію Верховного Суду України у постанові від 30 березня 2010 року у справі № 27/26908. У ній вказується, що мирова угода між боржником і кредитором у справі про банкрутство оновлює старе зобов'язання у цій же справі, але подібне посилання є недоречним. Вимоги конкретного кредитора ніяк не могли бути елементом цивільно-правової регулятивної угоди - новації. Адже предметом мирової угоди є грошові зобов'язання боржника перед кредиторами, які випливають із підстав, зазначених у пред'явлених кредиторами заявах про грошові вимоги до боржника. Саме вони припиняються відповідно до ст. 604 ЦК України. Йдеться про вимоги, що пред'являлися усіма кредиторами до боржника і становили регулятивні невиконані зобов'язання щодо повернення коштів. В той же час, такі вимоги з боку Г. на час затвердження мирової угоди просто не існували.

Регулятивні вимоги із невиконання кредитної угоди боржником на користь стягувача на той час вже припинилися, бо були замінені на охоронно-правові вимоги, і їхньою правовою підставою було вже не невиконання обов'язку щодо розрахунку з боку КС «Аккорд», а невиконання судового рішення від 2009 року. Як відомо, такі вимоги не розглядаються при затвердженні мирової угоди в господарському суді. Результати судового розгляду, встановлені у остаточному рішенні, не можуть переглядатися, це становить один із основних принципів справедливості судового розгляду, задекларованого у ст. 6 Конвенції з захисту прав людини і основоположних свобод. Такий принцип у ЄСПЛ називається “res judicata”, що означає незмінність остаточних судових рішень.

За будь-яких обставин мирова угода у господарській справі про банкрутство, оформлена процесуальною ухвалою суду, аж ніяк не може скасовувати рішення іншого суду (рішення є набагато вагомішим актом, ніж процесуальна ухвала) та ще й постановлене за правилами іншої юрисдикції. Адже за законом мирова угода укладається сторонами з метою врегулювання спору на основі взаємних поступок і може стосуватися лише прав та обов'язків сторін та предмета позову. Ви- 
конавче провадження № 15771498 відкрите щодо примусового виконання саме судового рішення у справі, де сторонами є Г. і боржник КС «Аккорд», а не у справі про банкрутство.

Крім того, закон про виконавче провадження встановив можливість закінчення виконавчого провадження при визнанні судом мирової угоди між стягувачем і боржником у процесі виконання. У природі існувало лише одне виконавче провадження за № 15771498 у справі № 2-2339/09. У справі про банкрутство КС «Аккорд» № 910/2219/13 ніякого виконавчого провадження державними виконавцями не відкривалося, отже не існує фізичної можливості укладання i судового затвердження будь-яких угод у процесі виконання рішення про банкрутство. Мирова угода у господарській справі укладалася та затверджувалася господарським судом не у процесі виконання рішення (такого виконавчого провадження немає), а внаслідок виконання приписів спеціального господарського законодавства. Стягувач у справі № 2-2339/09 ніколи і у жодний спосіб не укладав мирової угоди зі своїм боржником у процесі виконання судового рішення. Тож об’єктивно відсутнє існування правочину, який міг би бути підставою для закінчення виконавчого провадження. Крім того, закон визначає особу, яка отримує мирову угоду, підписану кредитором і боржником у процесі виконання судового рішення, а потім передає її до суду для затвердження. Саме за наявності вказаного у законі процесу мирова угода може вважатися належною. Як відомо, виконавче провадження у справі № 910/2219/13 не відкривалося, тож не існує і виконавців, які є обов'язковим суб'єктом процедури. Оскільки мирова угода в процесі їі затвердження у справі про банкрутство має іншу нормативну природу, вона не може вважатися мировою угодою в процесі виконання, а отже, не $є$ підставою для закриття виконавчого провадження за п. 2) ч. 1 ст. 49 Закону «Про виконавче провадження» .

Власне, не заслуговує на увагу також позиція державного виконавця з приводу того, що інтереси стягувача належно задовольняються в межах процедури про банкрутство. Досить показовою є позиція Європейського суду з прав людини у ситуаціях, коли існує остаточне рішення про стягнення з підприємства коштів у разі подальшого початку процедури банкрутства проти такого боржника. У цьому разі суд має встановити, чи є засіб, який полягає в реєстрації особи в якості кредитора відповідно до Закону України «Про відновлення платоспроможності боржника або визнання його банкрутом» ефективним та може забезпечити кращий захист прав заявника. При дослідженні цього питання суд зазначив, що Уряд не зміг надати будь-якого прикладу успішної та вартої уваги справи, у якій робітник отримував заробітну плату в результаті реєстрації в якості кредитора у справі про банкрутство після того, як він перестав бути стороною у виконавчому провадженні. У світлі таких обставин суд дійшов висновку, що поки правдою $€$ те, що у заявника був доступ до обох засобів захисту, Уряд не продемонстрував, що у справі про банкрутство у заявника в якості кредитора було б більше переваг, ніж у виконавчому провадженні. Тому суд дійшов висновку, що заявник був позбавлений можливості використання засобу захисту, запропонованого Урядом та дотримався вимог ст. 35 п. 1 Конвенції [4, п. 39-42]. 
Таким чином, абсолютно ніяких правових засад у діях державного виконавця відділу державної виконавчої служби Шевченківського РУЮ у м. Києві щодо винесення постанови від 25 грудня 2014 року про закриття виконавчого провадження № 15771498 у справі № 2-2339/09 при судовому розгляді відповідної скарги стягувача не було виявлено, і суд справедливо визнав бездіяльність виконавця незаконною (остаточне рішення у справі № 554/352/18 [5]). Це означає, що він повинен на виконання судового вердикту поновити виконавче провадження, незаконно закрите у 2014 році і здійснити процедуру виконання судового рішення. Здавалося б справедливість відновлена, але у цій площині залишилися певні запитання. Чи є такий порядок виконання остаточного рішення справедливим? Відверто можна сказати, що ні. Справедливості, дотримання якої від нашої держави вимагає Європейький суд з прав людини, тут немає ні в сутнісному вимірі (державний орган усіляко намагається порушити конвенційне право особи на взагалі отримання виконання судового вердикту), ні в темпоральному (упродовж десяти років остаточне рішення національного суду залишається невиконаним). Недотримання строків виконання рішення за позицією ЄСПЛ вважається самостійним правопорушенням. Тож, враховуючи стан національного законодавства з безліччю лазівок для торпедування цивілістичних принципів, небажання та низький фаховий рівень працівників виконавчої служби, привабливість відповідних корупційних схем для них нашій державі навряд чи скоро вдасться хоча б наблизитися до рівня світових демократій у досліджуваній сфері.

Подібні комбінації національної виконавчої служби, спрямовані на затягування провадження або взагалі на невиконання остаточних судових рішень, досить толерантно оцінюються українським судочинством, тоді як Європейський суд з прав людини з цього питання займає досить жорстку позицію. Показово вона проявляється у справі «Гаращенко проти України». За її фабулою рішення судів на користь заявника набрали законної сили, і 24 листопада та 4 грудня 2000 року державна виконавча служба відкрила виконавче провадження, яке тривалий час не виконувалося. Не задоволений тривалим виконанням рішень, 25 травня 2001 року заявник звернувся до суду з позовом до виконавчої служби з метою відшкодування матеріальної шкоди, спричиненої її бездіяльністю. 10 квітня 2002 року суд задовольнив вимоги заявника, зазначивши, що виконавча служба не вжила заходів для виконання рішень від 14 липня 2000 року та 26 жовтня 2000 року, і присудив йому відшкодування в сумі позову, яка має бути сплачена з державного бюджету. Суд також зауважив, що виконавча служба все ще має можливість стягнути ці кошти з боржника для покриття своїх витрат. 22 листопада 2002 року заявник звернувся до виконавчої служби з вимогою відкрити виконавче провадження. Однак, згідно з твердженнями заявника це провадження було відкрито тільки після того, як він подав декілька відповідних скарг до суду. Пізніше виконавчий лист заявника передавали від одного управління виконавчої служби до іншого з різних підстав; цей лист також було передано до Державного казначейства України для подальшого виконання, але згодом повернено назад до виконавчої служби. Крім того, остання зупиняла та поновлювала виконавче провадження декілька разів. Заявник подавав до судів численні скарги, стверджуючи про бездіяльність з боку 
виконавчої служби, але виконання рішень так насправді і не відбулося. Відтак, ЄСПЛ констатував порушення Україною пункту 1 статті 6 Конвенції щодо тривалого виконання рішення на користь заявника [6, п. 21-22].

При цьому для кваліфікації діяння як протиправного щодо надмірної невиправданої затримки виконання остаточного рішення суду мають враховуватися як сама тривалість провадження, так і специфічні ознаки, пов'язані з предметом виконання, наприклад є судові присудження грошовими чи ні. Суд щоразу повторює, що судовий розгляд та виконавче провадження є першою і другою стадією єдиного провадження. Таким чином, виконавче провадження не повинно відокремлюватись від судового і вони мають бути розглянуті в сукупності. Тож вимоги ст. 6 Конвенції про захист прав людини і основоположних свобод щодо розумності строків розгляду справи повинні застосовуватися і до тривалості виконавчого процесу. Лише за таких умов захист прав людини на суд буде чесним і справедливим.

\section{Jimepamypa}

1. Курс цивільного процесу : підручник; за ред. проф. В.В. Комарова; Нац. ун-т «Юрид. акад. України ім. Ярослава Мудрого». Х. : Право, 2011. 1352 с.

2. Гавриленко С. Самого лише отримання рішення суду на свою користь недостатньо для досягнення мети, задля якої люди звертаються до системи правосуддя - захисту порушених прав і свобод. Українська правда. URL: https://life.pravda.com.ua/columns/2018/07/24/232203/.

3. Справа № 2-2339/09. Архів Октябрського район. суду м. Полтави за 2009 р.

4. Рішення ЄСПЛ від 20 вересня 2005 року у справі «Трихліб проти України», заява № 58312/00. URL: https://zakon.rada.gov.ua/laws/show/980_409.

5. Рішення у справі № 554/352/18. Архів Октябрського районного суду м. Полтави за 2018 рік.

6. Рішення ЄСПЛ від 16 квітня 2009 року у справі «Гаращенко протии України», заява № 26873/05. URL: https://zakon.rada.gov.ua/laws/show/974_455.

\section{Анотація}

Гуйван П. Д. Своєчасне виконання остаточних судових вердиктів в Україні залишається хронічною проблемою. - Стаття.

Робота присвячена актуальному в Україні питанню правової організації своєчасного виконання остаточних судових вердиктів. Оскільки виконання рішень суду потребує за діяння спеціалізованих державних та приватних виконавчих органів, саме належне опосередкування їхньої діяльності становить головну задачу національної правової системи для забезпечення вимог Конвенції про захист прав людини і основоположних свобод. Адже від ефективності вчинків органів виконання залежить рівень довіри громадян до держави, у тому числі авторитет судової влади.

Стан виконавчих проваджень в українському правовому середовищі, у статті зазначається, що ситуація із виконанням судових рішень потребує суттєвого вдосконалення. Встановлено, що у цьому плані наше вітчизняне законодавство має значну кількість вад, а в деяких випадках здається, що окремі його положення спеціально напрацьовані для того, аби торпедувати виконавчий процес. У вказаному контексті вивчено та детально проаналізовано протиправні вчинки працівників виконавчої служби на прикладі конкретної справи. Зокрема, доводиться, що виконавець як учасник заключної стадії судового розгляду, мусить гарантувати якомога швидший результат провадження. Завдяки об'єктивним (неналежний стан вітчизняного законодавства у цій царині) та суб'єктивним (незацікавленість та безкарність відповідних службовців) чинникам ситуація із своєчасністю виконання остаточних рішень судів у нашій державі близька до колапсу. Це визнається і такою міжнародною правової інституцією, як Європейський суд з прав людини.

У науковій праці вказується, що тривалі затримки з виконанням судових рішень є самостійними правопорушеннями, і на них мусить жорстко реагувати український правозастосовний орган - суд. Разом 3 тим, констатовано, що національне правосуддя досить толерантно ставиться до порушників права особи на своєчасне виконання рішення у її справі. Наведено принципову позицію ЄСПЛ з подібного питання. Зроблено висновок, що виконавче провадження не повинно відокремлюватись від судового. Тож вимоги ст. 6 Конвенції про захист прав людини і основоположних свобод щодо розумності строків розгляду справи мають застосовуватися і до часу виконавчого процесу.

Ключові слова: розумний строк, своєчасне виконавче провадження. 


\section{Summary}

Guyvan P. D. Timely execution of final court verdicts in Ukraine remains a chronic problem. - Article. The work is devoted to the urgent issue of legal organization of timely execution of final judicial verdicts in Ukraine. As the enforcement of court decisions requires specialized public and private enforcement bodies to act, proper mediation of their activities is the primary task of the national legal system to meet the requirements of the Convention for the Protection of Human Rights and Fundamental Freedoms. After all, the level of public confidence in the state, including the authority of the judiciary, depends on the effectiveness of the actions of the enforcement bodies.

Analyzing the state of enforcement proceedings in the Ukrainian legal environment, the article states that the situation with the enforcement of court decisions requires substantial improvement. It is established that in this respect our domestic legislation has a considerable number of defects, and in some cases it seems that some of its provisions are specially designed to torpedo the executive process. In this context, the unlawful actions of the executive service employees were studied and analyzed in detail.

In particular, it is argued that the executor as a participant in the final stage of the trial must guarantee the soonest possible outcome of the proceedings. But, in fact, due to the objective (inappropriate state of domestic legislation in this area) and subjective (uninterested and impunity) officials, the situation with timely execution of final court decisions in our country is close to collapse. This is also recognized by such an international legal institution as the European Court of Human Rights.

Scientific work indicates that lengthy delays in the execution of court decisions are separate offenses. And the Ukrainian law enforcement agency - the court - must react strongly to them. However, it is stated that national justice is quite tolerant of violators of a person's right to timely enforcement of a decision in his case. The principled position of the ECHR on a similar issue is outlined. It was concluded that enforcement proceedings should not be separated from the judicial proceedings and should be considered in their entirety. So the requirements of Art. 6 of the Convention for the Protection of Human Rights and Fundamental Freedoms as to the reasonableness of the terms of the case should also apply to the length of the enforcement process.

Key words: reasonable time, timely enforcement proceedings. 